\title{
Subject Pool Identifier
}

National Cancer Institute

\section{Source}

National Cancer Institute. Subject Poolldentifier. NCI Thesaurus. Code C117053.

A sequence of characters used to identify, name, or characterize the subject pool. 